\title{
THE COLONIAL FOUNDATIONS OF MALAYSIA'S TERRORIST REHABILITATION PROGRAM
}

\author{
Laura Khor
}

\begin{abstract}
Malaysia's Terrorist Rehabilitation and Disengagement programs have shown positive results in detainee responses. Disengagement and de-radicalization are necessary elements in Malaysia's successful and comprehensive counter-terrorism strategies and policies. Malaysia's Terrorist Rehabilitation program employs academics, psychologists, policy makers, police, intelligence personnel, and religious leaders who have continually shaped this successful security program and anchored its' underlying disengagement security philosophy. The Malaysian Rehabilitation program's security philosophy and strategic framework have a unique history traced to the Malayan Emergency.
\end{abstract}

Keywords: Terrorist rehabilitation, terrorist de-radicalization, Malayan Emergency

\section{INTRODUCTION}

Countless academics and practitioners have studied various aspects of the Malayan Emergency and British counter-insurgency campaign. ${ }^{1}$ Is the Malayan Emergency and its lessons learned relevant and instructive today? As one academic asked, "[a]re there in fact any truly interesting 'lessons' to be gleaned from this 12-year campaign or were its circumstances too specific to have any relevance today?" 2 There are still interesting and relevant lessons from the Malayan Emergency. In order to appreciate the value of the intelligence success of Malaysia's Terrorist Rehabilitation program in counter-terrorism operations, the beginning of the program and the underlying security philosophy which shaped Malaysia's security framework will be analyzed. The Malaysian concept of detainee rehabilitation can be traced to the Malayan Emergency $^{3}$, which was a colonial idea and program further developed and adapted to address both Islamic radicalization and provide pathways for terrorist disengagement. ${ }^{4}$ The intelligence philosophy and successful policies in the Malayan Emergency served as 'lessons learned' for current Malaysian officials who have adapted them into intelligence and counter-terrorism success.

The Malayan Emergency offers the framework and guiding principles for successful counter-terrorism initiatives and policies in Malaysia. The Malaysian Government, learning from the successful foundation of colonial British counterinsurgency operations, accommodates, co-opts and confronts terrorism through counter-terrorism initiatives. Malaysia is both proactive and reactive. The varieties of programs and policies targeting both non-insurgent detainees and insurgents to break away from the insurgency developed during the Malayan Emergency have been 
adapted by the Malaysian Government. The concept of rehabilitation centres for terrorists, insurgents and non-insurgent detainees is not 'new' as the British and Greeks both used rehabilitation camps in Malaya, Kenya and Makronnissos. ${ }^{5}$

Malaysia has domestic and regional terrorist groups, such as the Kumpulan Mujaheddin Malaysia (KMM) and Jemaah Islamiah (JI), whose leadership is comprised of former fighters with the Mujaheddin in Afghanistan and who has been linked to Al Qaeda. ${ }^{6}$ The challenge facing Malaysia and other South East Asian nations is the linking of domestic and regional groups with Al Qaeda. The regional threat of Jemaah Islamiah has also affected Malaysia with twenty-two people arrested between December 9, 2001 and August 2002. ${ }^{7}$ The Malaysian cell is believed to be the largest in the JI network, with an estimated 200 members. According to Abuza: ${ }^{8}$

The Malaysian JI cell recruited actively among both Indonesian exiles and educated Malays. At least five senior JI members and recruiters were lecturers in the UTM. The twenty-two suspects who have been arrested in Malaysia are well-educated: twelve have university degrees, five are from institutions in the United States, Great Britain, and Indonesia, and the remainder from Malaysian universities. ${ }^{9}$

Malaysia faces internal and external Islamic radicalization, which has been a focus in pre-emptive government policies and administrations. The Malaysian Government described their Rehabilitation program as “...winning hearts and minds of the segments of society that are normally targeted by extremist and radical groups for recruitment, support and funding." ${ }^{10}$ Malaysia's security approach and strategy is focused on comprehensive and long-term policies, such as implementing and engaging their terrorist rehabilitation program, to aid the intelligence and security apparatuses and policies in Malaysia. In order to understand Malaysia's oldest operating rehabilitative security program, we have to look at its colonial past and foundations.

\section{COLONIAL FOUNDATIONS}

The Malayan Emergency officially began 1948 and ended in 1960. The British colonial system in Malaya had many opportunities during the Malayan Emergency to formulate successful "push"11 and "pull" 12 policies and programs. Colonial and Malayan/Malaysian policy makers implemented and adapted a range of push and pull policies and directives to ensure counter-insurgency success. Specifically, the inflexible push policies were detainment, banishment, and collective punishment while the pull polices of non-insurgent detainee rehabilitation, Surrender for Rewards policies, and the Special Operations Volunteer Force (SOVF) were flexible policy responses to ensure successful disengagement.

In Malaya, later Malaysia, the Special Branch interrogated and engaged with Surrendered Enemy Personnel (SEPs). The Special Branch understood their treatment of SEPs and CEPs was crucial to obtain information and to bring in more SEPs to further break down Communist cells. ${ }^{13}$ The SEPs formed a Special Operational Volunteer Force to fight guerrillas. Sunderland is of the view that: ${ }^{14}$ 
These were men prepared to operate against their ex-comrades either openly, as uniformed members of the armed forces, or clandestinely. In 1957 they numbered ten platoons, each of one sergeant, two corporals, and twenty-one enlisted men. The platoon leader was a commissioned officer of the police.

The security forces were using SEP information and SEPs against their former comrades. In May 1953, the SOVF was expanded to more than 180 former Surrendered Terrorists resulting in further intelligence and operational collaborations between soldiers and Surrendered Terrorists. The Surrendered guerrillas were vetted and debriefed by Special Branch to join the SOVF. Special Branch controlled the Special Operations Volunteer Forces, which was led by Police Lieutenants, for both regular activities and ' $Q$ ' jungle operations. ${ }^{15}$ Many expressed shock at how readily the surrendered terrorists turned on their former comrades. ${ }^{16}$ Some SEPs would return to the jungle within hours or even days of their surrender to kill or capture their comrades, who they spent months or years with in the jungle. ${ }^{17}$ The process to leave the jungle and the MCP was due to a variety of factors such as disillusionment with a losing cause, dissatisfaction with fellow group members, or even leadership problems. ${ }^{18}$ Clutterbuck argued that: ${ }^{19}$

During the months in which he was brooding on the question of whether to make the break, this prospect would engender a bitter hatred of the Party that had trapped him into this unbearable situation. This hatred would be focused on his immediate Communist boss - fanned by the awareness that this boss would show him no mercy if for one moment he suspected his thought of desertion. At the same time, he perhaps feared that, so long as any of the men in his gang remained alive, a chance encounter in a back alley, even in ten or twenty years' time, could you prove more than embarrassing. He would then sleep more soundly if they were dead.

The disengagement process was complex. As Pye learned: ${ }^{20}$

They were not only generally prepared to cooperate with the authorities but usually eager to lead patrols back into the jungle to attack their former comrades. Even when this meant killing people with whom they had lived and worked for many years, they were not troubled by the prospect, since their break with the party had been a personal one. They no longer had any ties with those in the party; they had to establish new ones with those in the government.

The Surrender for Rewards program was a useful policy program for the Special Branch to help with SEPs disengagement from the Communist insurgency. Special Branch officers worked very closely with SEPs and even used them to help in interrogations. As Clutterbuck explained, the initial allure and recruitment into the Communist insurgency was the opportunity for a better life. ${ }^{21}$ The Surrender for Rewards policies and programs aided disengagement for SEPs by giving them the money for a new life away from the communist insurgency and cell. The surrender terms evolved throughout the Emergency, but the final Merdeka (Freedom) Offer 
leaflets were the most generous surrender terms. ${ }^{22}$ The government was successful with the Surrender for Rewards program and gathering intelligence from the SEPs. As Laqueur argued, "[t]his damaged the moral of those remaining in the jungle and provided intelligence to the British commanders." 23 The persuasion to disengage and have a new life proved fatal to the Communist insurgency. The unique pull program targeting non-insurgent detainees was the Taiping Rehabilitation Camp.

In the Malayan Emergency, the detention and banishment orders resulted in many innocents being drawn into the detention camps or sent back to China. These draconian policies were heavy handed and caused increased distrust and fear by the Chinese populations of Government agents, especially the Police. The unique pull policy of the Taiping Rehabilitation Camp was developed to negate the more punishing, and later paused then re-started, push policies of mass detentions and banishment (deportation) that targeted the Chinese population. It was argued that: ${ }^{24}$

The process of isolation of the 'hard core' can only be permanently successful if some alternative object of affiliation, stronger than the bandits and at the same time inspiring greater fear, can be introduced to which the floating Chinese can attach themselves.

The camp and program was suggested by E. D. Fleming, the Secretary for Chinese Affairs in Malaya, based loosely on the Makronisos experiment for soldiers in Greece. The policy was changed to suit the detainees and situation in Malaya. ${ }^{25}$ The Taiping Rehabilitation Camp developed during the Malayan Emergency was an exclusive program designated for non-insurgent detainees. According to one source: ${ }^{26}$

It should be appreciated that the inmates of Macronnissos are in fact conscripted soldiers and, therefore, the principles upon which the Macronnissos experiment was run were modified to suit the problem in Malaya. Military discipline was not considered suitable for the Chinese - particularly as the soldier is traditionally at the bottom of the Chinese class system.

The Taiping Rehabilitation Camp was founded at the Turf Club in Taiping, Perak, Malaya. The camp was opened officially on December 27, 1949 with support from the British Government and the Malayan Chinese Association (MCA). The rehabilitation camp was not merely a top-down government policy as grassroots groups were involved in the success of the program. The Malayan Chinese Association "have not only undertaken the resettlement of detainees but have contributed large sums of money and quantities of equipment and materials for use by the camp." 27 The facility with classrooms and workshops, started with 54 detainees, a number that grew exponentially throughout the Emergency. ${ }^{28}$

The overall objective of the Taping Rehabilitation Camp was to act as a pull for the Government "to rehabilitate communist-influenced Chinese detainees in the moral and material sense, so that they may take their places in the community without being a further danger to security." 29 The Taiping Rehabilitation Camp was a policy change from the containment and punitive policies pursued by the Government during 1945-1948, with selective banishment and detention. Detainees were treated not as threats to the state, rather as people who could be rehabilitated through a less punitive 
security ideology which combined job training with a definitive idea of "success" to sway the detainee from the appeal of Communism and the Malaysian Communist Party. As High Commissioner, Sir Henry Gurney, argued that: ${ }^{30}$

This [Rehabilitation camps] may seem to some people a little unpractical and idealist, but it is often because some people cannot find enough idealism in the democratic faith that they turn to Communism. I personally regard it as an inspiring and worth-while job and if we can succeed in it we shall be achieving the first true and decisive victory over Communism in South East Asia.

The success of the "Experiment" depended on the idea the pathway out of Communism would be achieved through proactive policies of education and resettlement into the community. The understanding of root causes of greed and grievance leading to possible recruitment and involvement, voluntary or not, with the MCP were remedied through the Taiping Rehabilitation Camp.

The Taiping Rehabilitation program addressed the deportation and mass detention government policies based upon the premise specific populations were security threats and the cause of the Communist insurgency. Henderson notes that: ${ }^{31}$

We must admit that the bulk of the Chinese in Malaya are here to stay; we must abandon the view that every supporter of the communists is permanently lost to society; and we must learn as rapidly as we can how to counter the influence of communism. Taiping Rehabilitation Camp is of vital importance.

The Taiping Rehabilitation provided a starkly different environment from the detention camps; which because of their increasing numbers created an intelligence backlog and a breeding ground for radicalization and recruitment by the Communists. The Emergency Regulations implemented at the beginning of the Emergency created vast government powers combined push and pull policies to be used effectively for the population and the potential, wavering, and hardcore insurgents.

Detainee selection by Special Branch, Taiping Rehabilitation Officials and Detention Camp personnel allowed for the success of the program and was vital to the general atmosphere. The detainees were carefully selected and monitored throughout their entire rehabilitation experience. It was argued that: ${ }^{32}$

The process of isolation of the 'hard core' can only be permanently successful if some alternative object of affiliation, stronger than the bandits and at the same time inspiring greater fear, can be introduced to which the floating Chinese can attach themselves."

The process of disengagement at Taiping was not only emotional and social disengagement, but also physical disengagement from the Communist insurgency. In order to prevent radicalization of detainees' families relief was offered by the government: ${ }^{33}$ 
In cases where families are undergoing great hardship application is made to the Social Welfare Department which grants such relief as is considered necessary. This service is greatly appreciated by the detainees.

The lessons learned from the Taiping experiment was accomplished by the role of government and non-governmental agencies working together for the greater good of the detainee, providing opportunities for personal and economic growth, care for the detainee's families while under rehabilitation, and provided physical disengagement from the insurgency and "hard-core" sympathizers and supporters. The focus on a vocational trade is a hallmark of the Taiping Rehabilitation program. The Taiping Rehabilitation Camp required three interviews for each detainee. Interviews were conducted at the detainees' arrival and mid-way through the program to determine progress and release options. ${ }^{34}$ The final interview, the exit interview, occurred at the conclusion of the detainees' rehabilitation and was completed by the Superintendent. ${ }^{35}$

Insuring each detainee left the Taiping Rehabilitation program with a vocational trade was the goal of the program. The training offered by the program provided opportunities to work in the greater community of Taiping through trade apprenticeships: ${ }^{36}$

It is possible to keep skilled tradesmen in practice; to start young men learning the trade of their choice so that after release they may continue their apprenticeship; and to discover detainees' aptitude, so that the field-worker type who may never for reason of family economy have had the opportunity of starting to learn a trade may now have that opportunity. Where camp facilities for vocational training are inadequate arrangements are made for detainees to be paroled and apprenticed to trades in the town of Taiping.

The detainees were appreciative of the program, therefore requiring minimal security. ${ }^{37}$ "Detainees have so far shown no desire to escape although if they wished to do so it could be achieved with little danger." 38 All detainees were afforded privileges and freedoms not permitted in other detention camps throughout Malaya. ${ }^{39}$ The use of rehabilitation centers and the success of such rehabilitation programs were mentioned throughout the Emergency. In particular: ${ }^{40}$

Rehabilitation centres to redirect the sympathies of people detained for assisting the terrorists have had a remarkable success. Out of 3 , 600 persons unconditionally released from the centres, only 25 have subsequently come to notice for subversive activities. The centres are arranged on the 'open gate' principle, with freedom for detainees to visit nearby towns, spacious dormitories, canteens, cinemas, hospitals and other facilities. The detainees learn to read and write Chinese or Malay or English and study other subjects, including farming or some other trade.

At the beginning of the Malayan Emergency there were only a handful of camps, comprised of small numbers. Barber mentioned, "[a]t the beginning of the war 
there was only one camp where 'hopeful cases' could be trained to become useful citizens again." ${ }^{41}$ Throughout the Emergency, there were a variety of classifications based on intense interrogations of the detainee upon their capture or surrender. Those living in the New Villages ${ }^{42}$ also could be sent to the rehabilitation camps. ${ }^{43}$ During the Emergency, these camps and effectiveness were described by J. B. Perry Robinson as, "[m]any thousands have been cured in the Rehabilitation Camps (notably Taiping) and have re-entered civil life as orderly well-disposed citizens." ${ }^{, 4}$ In April 1950, Lieutenant-General Sir Harold Briggs was appointed Director of Operations in Malaya. Briggs was one of the new thinkers who recognized the importance of winning the people in order to win the Emergency. He prioritized the isolation of the Communist Terrorists from the squatters as an essential first step to successfully defeat the insurgency and win the Emergency. In order to isolate the insurgency from their base of support, the Briggs Plan, ${ }^{45}$ was implemented. Gradually the Briggs Plan rebuilt government and administrative presence in rural Chinese areas despite guerrilla intimidation, ambushes, strikes and killings.

The Briggs Plan was a shift in colonial policy. In 1950, the Resettlement Plan took shape with a bill passed by the Legislative Council authorizing the resettlement of squatters in the jungle. The Resettlement Plan started in June 1950 and was almost completed by the end of 1951 with over 500,000 squatters and an estimated 600,000 estate laborers resettled. ${ }^{46}$ The time period after 1952, New Villages (previously resettlement areas) were focused on "qualitative issues" of life in New Villages. ${ }^{47}$ Regarding the New Villages a government official said, " $[\mathrm{t}]$ he degree of cooperation we get from a village is in almost exact proportion to what we have put into it.",48

The success of non-insurgent rehabilitation programs is one lesson learned from the Malayan Emergency. The continuing security philosophy of disengagement is another legacy. The Malayan Emergency had an effect on Malaysia's security philosophy of holistic and long-term approaches to security threats. Dr. Too Chee Chew, better known as C. C. Too, was the head of the Psychological Warfare Section for Malaya and Malaysia for almost thirty years. His work and his ideas helped Malaya, a British Colony; successfully counter the Communist terrorists and their threats to destabilize the country. C. C. Too was a man mentioned throughout the Malayan Emergency literature, yet he never wrote an autobiography about his life, successes and times during and after the Malayan Emergency. This is unfortunate, but his legacy and influence continues in current Malaysian security frameworks and approaches. Too is often quoted as having a clear understanding of Captured Enemy Personnel (CEPs) and Surrendered Enemy Personnel (SEPs) during the Malayan Emergency. As Barber explained: ${ }^{49}$

Too's major rules were: Don't preach. Don't theorize. Never say 'I told you so.' No propaganda based on hatred. One of Too's favourite lines was, "You are a human being and we all make mistakes"

C. C. Too understood the lessons and features necessary for successful disengagement methods and approaches. C. C. Too stated that: ${ }^{50}$

It's no good hating the CTs in your propaganda," said Too. "You may hate some of the things they do, but you have to remember 
that when you are sending leaflets or messages to CTs in the jungle, you can never be sure of what kind of a Communist you're going to address. He might be genuinely sincere- he might be a waverer who realizes he's made a mistake and wants to escape but daren't - or he could be a criminal who doesn't really know what Communism is about. You've got to find a formula that fits every kind of CT.

Too's attitude has had a direct impact on Malaysia's current counter-terrorism policies and its underlying philosophy of individuality. In Malaysia, the detained terrorists, similar to Communist Terrorists better known as CTs, are understood to have joined for a variety of reasons and have a range of support for their cause. The current security approach is flexible to adapt to each individual terrorist case.

Malaysia successfully operated disengagement and de-radicalization programs and policies learning from their colonial counter-insurgency past. ${ }^{51}$ The successful institutional governance powers, laws, and policies in the Malayan Emergency were expanded and adapted to internal and external security threats challenging Malaysia. The adapted policies and programs allowed disengagement paths and routes from insurgent and terrorist groups. The basic framework and laws were modified for the context, security culture and internal and external security threats challenging Malaysia. The old threats of Communism and the new threats of radicalized Islamist groups and individuals have resulted in the constant learning and adaption to security threats by the Malaysian Government. Malaysia has adapted to a new security environment with an old security paradigm.

The Malaysian concept of detainee rehabilitation originated in the Malayan Emergency ${ }^{52}$ was a colonial idea and program developed and adapted to provide pathways for terrorist disengagement and de-radicalization. De-radicalization is a process that can occur through "social, political and economic changes within a pluralist context." M3 Malaysia has a "comprehensive de-radicalization" disengagement program to counter security threats. Disengagement has a variety of meanings, definitions and values depending on the context and groups involved. ${ }^{55}$ As Horgan argued: ${ }^{56}$

The promotion of disengagement (in whatever way, and at whatever level) will necessarily have to be tailor-made to not only the specific movement in question, but will need to be carefully positioned within the context of the specific socio political or other issues experienced by the non-state movement and opposing regime at any particular moment in time.

Malayan Emergency officials promoted disengagement through policies that were context and culture specific. The current Malaysian Terrorist Rehabilitation program learned from the successful push and pull policies of the Malayan Emergency while adapting to current and future security threats.

The Malaysian government, to counter radical Islamic terrorists, has utilized the counter-insurgency strategies of the past to ensure its success in the highly securitized present. The Malayan Emergency must be understood in the context and 
culture of colonial Malaya. The subsequent guerrilla warfare campaigns and counterinsurgency operations were conducted by a colonial power within a colony against a foreign ideology. The "Lessons Learned" must be understood within the time period and colonial framework, as not all lessons from the Emergency are adaptable to the current counter-insurgency operations of today.

The Malayan model of physical disengagement and rehabilitation operated within a highly coercive overall framework of mass deportations, executions of uncooperative CEPs, and mass detentions. The highly selective use of SEPs in the SOVF, the opportunity for non-insurgent detainee rehabilitation at the Taiping Rehabilitation Camp were limited to extremely small numbers of non-insurgent detainees and SEPs in comparison to the thousands held in detention or deported. ${ }^{57}$

The rehabilitation program is one such lesson learned that many countries can adapt as intelligence and security policy with long term and short term results. The rehabilitation program operated within the Emergency Regulations, which were and still are an issue of debate between academics and legal scholars. The Emergency Regulations allowed detention and deportation in a legal framework. The most controversial of these powerful and thorough Emergency Regulations were 17C and 17D. ${ }^{58}$ It is estimated some 34,000 people had been detained during the Emergency under Regulation 17-D. ${ }^{59}$

The colonial success of intelligence and counter-insurgency operations has been successfully transformed to combat Malaysia's current security threats. The Taiping Rehabilitation camp provided pathways of disengagement and re-education for detainees. The "lessons learned" of physical disengagement, training for a better life through government programs and policies, government and non-governmental cooperation, and thorough aftercare programs after successful Rehabilitation Camp graduation with the community were continued and adapted for the numerous security challenges for the Malaysia of today. The success of the "pull" policies of Surrender for Rewards program and the implementation of the Taiping Rehabilitation program should not be a surprise. As Art and Richardson argue that: ${ }^{60}$

The opportunity to turn against one's comrades is far more likely to be an attractive proposition to members of an organization facing defeat or under intense pressure than it is to group members who have reason to be confident in their ability to prevail.

The Taiping Rehabilitation camp program and policies worked with both local groups and the government to reintegrate detainees back into society and trained them with skills to gain employment. The Taiping Rehabilitation camp was the first of many policies that was specifically adapted to the people and the Emergency situation in Malaya. In 1950, the Taiping Rehabilitation program had a capacity of 18 huts accommodating 34 men in each hut. ${ }^{61}$ The average stay for a detainee was $51 / 2$ months. ${ }^{62}$ Coupled with Taiping's rigorous selection process, ${ }^{63}$ the Taiping Rehabilitation Camp accommodated a small number of detainees. To fully understand how small the Taiping Rehabilitation Camp was, between June and July 1952, 154 detention orders were signed, raising the total of signed detention orders to 28,362 with a total of 6,556 persons in detention. ${ }^{64}$ 


\section{CONCLUSION}

The challenge for many terrorist rehabilitation programs is defining 'success' and many countries rates of success are racked with quantitative and qualitative challenges. The many questions of determining 'success' does not factor in the challenges of disengagement, whether success is defined as physical disengagement from the group or the more challenging aspect of disengagement, a psychological break from the movement or terrorist group. Malaysia's definition of 'success' in the rehabilitation program is flexible as not all detainees completely abandon the political ideals of their movement; rather they choose to physically disengage. This is one of the challenges in assessing effectiveness, not only of Malaysia's Terrorist Rehabilitation program, but also all other global terrorist rehabilitation programs. Malaysia's Terrorist Rehabilitation program operates within Malaysia's legal framework and is the major disengagement policy aimed at terrorists and terrorist groups.

The program is carefully monitored by the Royal Malaysian Police and is supported by the government. Malaysia's Terrorist Rehabilitation program affords intelligence officers long-term contact and dialogue with detainees to understand their pathways into terrorist groups and organizations. The rehabilitation program separates the more 'hard-line' from the wavering terrorists, which eases information gathering for Malaysian Special Branch. This separation also minimizes radicalization within the rehabilitation program.

In recent years, terrorist rehabilitation programs have been implemented around the world in a variety of post-conflict situations and states. The rehabilitation programs are successful if they are adapted for the culture, state or states, and detainees. The adaptability of the programs is to address the root causes of the detainees, whether ideological, psychological, political motivated and to try and bring them back to the mainstream. The disengagement programs, especially those operated within prisons, are successful because prisoners are physically removed from the movement. The successful rehabilitation programs separate detainees to ensure that radicalization in prison does not occur. The opportunity to have a physical distance from the movement allows the opportunity for a detainee to further disengage and, possibly, permanently walk away and disengage from the movement. The overall approach is for disengagement and, in some programs, to work towards deradicalization.

Terrorist rehabilitation programs are not a silver bullet solution. ${ }^{65}$ Malaysia's terrorist rehabilitation programs have been adapted to their specific security threats, legal framework, context, and culture. The important lessons of understanding terrorists and their motivations are a dominant security doctrine and policy framework in Malaysia. Malaysia has learned from their Communist counter-insurgency history to ensure current terrorist reintegration and rehabilitation success.

The challenge of defining and understanding 'success' in terrorist rehabilitation is an area for current and future research. Many countries, Western in particular, pay an inordinate amount of attention to immediate results and statistics from such programs which is short sighted and completely misses the point of counter-ideology, disengagement and de-radicalization. It is a process to become 
radicalized or to join a militant group, and the process to 'walk away', disengage or even become de-radicalized will also take time, depending on the individuals and some are so 'hard core' that de-radicalization and disengagement will never happen. The concept of success and how countries operate within what their understanding of success and successful programs merit further research.

Malaysia's security philosophy and rehabilitation program have "focused on identifying and addressing the deep-seated causes of terrorism, rather than relying on military strikes against suspected terrorists and countries accused of harbouring terrorism." 66 The Malaysian Government has learned from its successful counterinsurgency colonial past to address root causes with a comprehensive approach to counter terrorism by adapting push and pull policies. In response to the academic that asked, "[a]re there in fact any truly interesting 'lessons' to be gleaned from this 12year campaign or were its circumstances too specific to have any relevance today?"67 The answer is a resounding yes. There are still interesting and relevant lessons from the Malayan Emergency for today.

\section{NOTES}

${ }^{1}$ For example, Paul Dixon, “'Hearts and Minds'? British Counter-Insurgency from Malaya to Iraq," Journal of Strategic Studies, Vol. 32, No. 3, 2009, pp. 353-381. Huw Bennett, "A very salutary effect: The Counter-Terror Strategy in the Early Malayan Emergency, June 1948 to December 1949," Journal of Strategic Studies, Vol. 32, No. 3, June 2009, pp. 415-444.

${ }^{2}$ David H. Ucko, "The Malayan Emergency: The Legacy of a Counter-Insurgency Success Story," Defence Studies, Vol. 10, Nos. 1-2, March-June 2010, p. 14.

${ }^{3}$ The Malayan Emergency refers to the guerrilla war from 1948-1960.

${ }^{4}$ The definition of disengagement in this article is:

"Disengagement: the process whereby and individual experiences a change in role or function that is usually associated with a reduction of violent participation. It may not necessarily involve leaving the movement, but is most frequently associated with significant temporary or permanent role change. Additionally, while disengagement may stem from role change, that role change may be influenced by psychological factors such as disillusionment, burnout or the failure to reach the expectations that influenced initial involvement. This can lead to a member seeking out a different role within the movement," in John Horgan and Tore Bjorgo, Leaving Terrorism Behind: Individual and Collective Disengagement, London: Routledge, 2009, p. 152.

${ }^{5}$ Caroline Elkins, "The Struggle for Mau Mau Rehabilitation in Late Colonial Kenya," The International Journal of African Historical Studies, Vol. 33, No. 1, 2000, pp. 25-57.

${ }^{6}$ Zachary Abuza, "Tentacles of Terror: Al Qaeda's Southeast Asian Network," Contemporary Southeast Asia, Vol. 24, No. 3, December 2002, p. 428.

${ }^{7}$ Ibid., p. 450.

${ }^{8}$ Ibid., p. 453.

${ }^{9}$ Ibid., p. 453.

${ }^{10}$ From the response of the Malaysian Government to the 18 February 2008 CTITF letter. Received on 9 October, 2008 from the United Nations Counter-Terrorism Implementation Task Force, "First Report of the Working Group on Radicalisation and Extremism that Lead to Terrorism: Inventory of State Programmes", $<$ http://www.un.org/terrorism/pdfs/radicalization.pd>.

${ }^{11}$ A "push" policy is understood to be similar to "stick" found in "carrot and stick" counter insurgency literature. These policies are understood to be more punitive or coercive in 
approach. The definition for "Push" policies uses Bjorgo's definition: "Push" relates to negative social forces and circumstances which make it unattractive and unpleasant to remain in a particular social environment. . ." in Bjorgo, "Process of disengagement from violent groups of the extreme right." See Bjorgo and Horgan (eds.), Leaving Terrorism Behind, p. 36. ${ }_{12} \mathrm{~A}$ "pull" policy is understood to be similar to "carrot" found in "carrot and stick" counterinsurgency literature. These policies are less punitive and holistic in approach. Pull policies again use Tore Bjorgo's definition: “.... whereas 'pull' refers to factors attracting the person to a more rewarding alternative." Ibid., p. 36.

13 "To some people, the word "interrogation" conjures up visions of red-hot pokers. Torture is, in fact, the most shortsighted method of trying to get information; however great the immediate rests with the results may seem to be, they are always more than paid for by the losses in the long run - as the Germans, Russians, and French have found in their own attempts to defeat guerrillas. This is not only because torture is immoral, and must eventually turn the people against us, but also because, although torture may induce the victim to tell us what happened yesterday or even what is going tonight, it will not make him into an agent who will keep up his contacts with the Communists and betray them to us," in Richard Clutterbuck, The Long Long War: The Emergency in Malaya 1948-1960, London: Cassell \& Co., 1966, pp. 97-99.

14 "To an American eye, the Malayan police would appear to have been organized on semimilitary lines. Before the great expansion of the Emergency, the leadership of the police had been an elite group of university graduates, who were termed "officers" as against the " rank and file." Both socially and professionally, the colonial police officer was on a par with officers in the armed forces of the Crown. His status was thus very different from that of American police officer, a fact that lends significance to the above statement that the platoon was led by a commissioned officer of the police, " in Riley Sunderland, Antiguerrilla Intelligence in Malaya, 1948-1960, Santa Monica: RAND Corporation, 1964, p. 50, <http://www.rand.org/pubs/research_memoranda/2005/RM4172.pdf>

${ }^{15}$ Lucien Pye, Guerrilla Communism in Malaya: Its Social and Political Meaning, Princeton: Princeton University Press, 1956, p. 364; Leon Comber, Malaya's Secret Police 1945-60, The Role of the Special Branch in the Malayan Emergency, Singapore: Institute of Southeast Asian Studies (ISEAS), 2008, p. 4; Kumar Ramakrishna, Emergency Propaganda: The Winning of Malayan Hearts and Minds 1948-1958, Surrey: Curzon Press, 2002, p. 142.

${ }^{16}$ These were namely General Sir Frank Kitson and Lieutenant-Colonel Spencer F. Chapman. One example of an SOVF operation can be found in Roy Follows with Hugh Popham, The Jungle Beat: Fighting Terrorists in Malaya, 1952-1961, London: Cassell, 1990, pp.126-130.

${ }^{17}$ Richard Clutterbuck, Riot and Revolution in Singapore and Malaya 1945-1963, London: Faber \& Faber, 1973, pp. 181-183; Pye, Guerrilla Communism in Malaya.

${ }^{18}$ Ibid. "Not all SEPs were traitors. Some simply surrendered and returned to civil life after a period of rehabilitation, having betrayed no one. Others - especially senior ones late in the Emergency - came out realizing that the war was lost and with the humane intention of bringing their scattered commands out of the jungle with the minimum loss of life. Some cooperated with Special Branch over a period of several months, keeping their own defection strictly secret, and going out to lead in their branches and platoons, one by one," in Clutterbuck, Riot and Revolution in Singapore and Malaya 1945-1963, p. 183.

${ }^{19}$ Ibid., p. 182.

${ }^{20}$ Pye, Guerrilla Communism in Malaya, pp. 338-339.

21 "The Communists seemed to offer them the opportunity to get somewhere, to be someone," Clutterbuck, The Long Long War, p. 103.

${ }^{22}$ The terms were written in English, Malay, Tamil and Chinese on printed leaflets. See Clutterbuck, The Long Long War, pp. 104-105.

${ }^{23}$ Walter Laqueur, Guerrilla Warfare: A Historical \& Critical Study, London: Transaction Publishers, 2002, p. 290. 
24 "Footnote 107: CO537/4753 reads "Statement by the High Commissioner for Malaya, Annexe 'A' to minutes of the $16^{\text {th }}$ meeting of the BDCC (FE), 28 Jan. 1949," in Bennett, "The Counter-Terror Strategy in the Early Malayan Emergency June 1948 to December 1949," p. 432.

${ }^{25}$ On the limited literature on the Makronisos experiment, the spelling has appeared as Makronisos and Macronnissos.

${ }^{26}$ K. J. Henderson, "The Experiment at the Taiping Rehabilitation Camp", Heussler Papers, Box 14, RHO, July 1950, p. 22.

${ }^{27}$ Ibid., p. 15.

${ }^{28}$ Ibid., p. 4.

${ }^{29}$ Ibid., p. 2.

${ }^{30}$ Sir Henry Gurney, "Legislative Council, $29^{\text {th }}$ September, 1949" in Communist Banditry in Malaya: Extracts from Speeches The High Commissioner Sir Henry Gurney, Kuala Lumpur: H. T. Ross, Government Printer, undated, p. 8.

${ }^{31}$ Henderson, "The Experiment at the Taiping Rehabilitation Camp," p. 3.

${ }^{32}$ Footnote 107 in Bennett, "The Counter-Terror Strategy in the Early Malayan Emergency," p. 432.

${ }^{33}$ Henderson, "The Experiment at the Taiping Rehabilitation Camp," p. 14.

${ }^{34}$ Ibid., p. 11.

${ }^{35}$ Ibid., p. 11.

${ }^{36}$ Ibid., p. 8.

${ }^{37}$ Ibid., p. 11.

${ }^{38}$ Ibid., p. 11.

${ }^{39}$ Ibid., p. 11.

40 "APPENDIX II: The Emergency in Malaya”, Malaya: The Making of a Nation, Central Office of Information Reference Pamphlet, London: Her Majesty's Stationery Office, No. 27, May 1957, p. 53.

${ }^{41}$ Noel Barber, The War of the Running Dogs, London: Collins Publishing, 1971, p. 89.

${ }^{42}$ This is not to argue that New Villages were immediately popular or without criticisms or problems. Refer to Paul Markandan, The Problem of New Villages in Malaya, Singapore: Donald Moore, 1954; W. C. S. Corry, A General Survey of New Villages: Report to His Excellency Sir Donald MacGillivray, Kuala Lumpur: Government Press by G.A. Smith, 1954. This is not to overstate that the resettlements and New Villages were without problems. "By the beginning of 1952, the physical resettlement of largely Chinese squatter families was four-fifth completed: some 400,000 people in some 400 new villages. It was soon to be admitted that speed had been achieved only at the sacrifice of other desirable features-“ particularly the careful selection of sites for resettlement in the light of the means of livelihood of the settlers, the best use of available land, adequate access roads' - and required a great exercise of imagination to assert that the people in the villages had now been brought under effective government control," in Anthony Short, The Communist Insurrection in Malaya 1948-1960, New York: Crane, Russak \& Co., 1975, pp. 293-294.

${ }^{43}$ J. B. Perry Robinson, Transformation in Malaya, London: Martin Secker \& Warburg, 1956, p. 95.

${ }^{44}$ Ibid., p. 95.

${ }^{45}$ The Briggs Plan was a Report that provided recommendations to the BDCC on May 24, 1950. The Report was titled Federation Plan for the Elimination of the Communist Organisation and Armed Forces in Malaya.

${ }^{46}$ Hack argued that "with the support of Sir Henry Gurney as High Commissioner, he launched the 'Briggs Plan'. This replaced ad hoc responses to the squatter problem with an integrated approach to population and spatial control. Its five main constituent parts were as follows: (1) Comprehensive resettlement of over 500,000 squatters, and regroupment of up to 600,000 estate labourers. Started in June, this was mostly complete by the end of 1951, after which the emphasis shifted from movement to qualitative issues. (2) Resettlement areas 
(later 'New Villages') were brought under government administration, with resettlement officers and the intention of extending services to them." See Karl Hack, "The Malayan Emergency as counter-insurgency paradigm”, Journal of Strategic Studies, Vol. 32, No. 3, June 2009, p. 4.

${ }^{47}$ Ibid., p. 4.

${ }^{48}$ Clutterbuck, Riot and Revolution in Singapore and Malaya 1945-1963, p. 190; Harry Miller, Menace in Malaya, London: Harrap, 1954, p. 218.

${ }^{49}$ Barber, The War of the Running Dogs, p. 118.

${ }^{50}$ Ibid., pp. 117-118.

${ }^{51}$ De-radicalization is defined as: "De-radicalisation is another process of relative change within Islamist movements, one in which a radical group reverses its ideology and delegitimizes the use of violent methods to achieve political goals, while also moving towards an acceptance of gradual social, political and economic changes within a pluralistic context. A group undergoing a de-radicalization process does not have to ideologically abide by democratic principles, whether electoral or liberal, and does not have to participate in an electoral process. De-radicalization is primarily concerned with changing the attitudes of armed Islamist movements towards violence, rather than toward democracy. Many deradicalized groups still uphold misogynist, homophobic, xenophobic and anti-democratic views. As distinct from the ideological level, de-radicalization can occur on the behavioral level only. On that level, de-radicalization means practically abandoning the use of violence to achieve political goals without concurrent process of ideological de-legitimization of violence. De-radicalization can occur in only one of the two levels," in Omar Ashour, The De-Radicalization of Jihadists: Transforming armed Islamist movements, London: Routledge, 2009 , p. 6.

${ }^{52}$ The Malayan Emergency refers to the guerrilla war from 1948-1960.

${ }^{53}$ Ashour, The De-Radicalization of Jihadists, p. 6.

${ }^{54}$ There are many levels of de-radicalization. The definition of comprehensive deradicalization is Ashour's definition: "comprehensive de-radicalization refers to a successful de-radicalization process on the three levels (ideological, behavioural and organizational)," see Ibid., p. 6; Also "The distinction between disengagement and deradicalization recognizes that disengagement is a necessary condition or antecedent of deradicalization. Governments often send disengaged terrorists who still hold radical views back into society, and these individuals may re-engage with terrorist groups for a variety of reasons. What the ideal-type, comprehensive rehabilitation programs aim to do is to make sure that detainees leave the programs as deradicalized individuals and that this condition is maintained through aftercare programs, " in Rohan Gunaratna, Jolene Jerard and Lawrence Rubin (eds.), Terrorist Rehabilitation and Counter-Radicalisation: New Approaches to Counter Terrorism, New York: Routledge, 2011, p. 3.

${ }^{55}$ Ibid.; Bjorgo and Horgan, Leaving Terrorism Behind; John Horgan, Walking Away from Terrorism: Accounts of Disengagement from Radical and Extremist Movements, New York: Routledge, 2009; Ashour, The De-Radicalization of Jihadists; John Horgan and Kurt Braddock, "Rehabilitating the Terrorists?: Challenges in Assessing the Effectiveness of Deradicalization Programs," Terrorism and Political Violence, Vol. 22, No. 2, 2010, pp. 267291; John Horgan, "Deradicalization or Disengagement? A Process in Need of Clarity and a Counterterrorism Initiative in Need of Evaluation," Perspectives on Terrorism, Vol. 2, No. 4, June 2008.

${ }^{56}$ Ibid., p. 7.

57 "Extract from the Federation of Malaya Monthly Newsletter No. 42 for the period $16^{\text {th }}$ June to $16^{\text {th }}$ July, 1952" CO1022/132, Kew Gardens: The National Archives, p. 15.

${ }^{58}$ Robert William Komer, "The Malayan Emergency in Retrospect: Organization of A Successful Counterinsurgency Effort," Santa Monica: RAND, February 1972, p. 36 <http://www.rand.org/pubs/reports/2005/R957.pdf>. The issue of detention is explained further in Anthony Short, In Pursuit of Mountain Rats: The Communist Insurrection in Malaya, Singapore: Cultured Lotus, 2000. 


\footnotetext{
${ }^{59}$ Ibid., pp. 36-37.

${ }^{60}$ Robert J. Art and Louise Richardson, Democracy and Counterterrorism, Washington, D.C.: United States Institute of Peace (USIP) Press, 2007, pp. 574-575.

${ }^{61}$ Henderson, "The Experiment at the Taiping Rehabilitation Camp", p. 11.

${ }^{62}$ Ibid., p. 19.

${ }^{63}$ Ibid., pp. 5-6.

${ }^{64}$ CO1022/132, The National Archives, p. 15.

${ }^{65}$ John Horgan, "Conclusions" in John Horgan, Walking Away from Terrorism: Accounts of Disengagement from Radical and Extremist Movements, London: Routledge, 2009.

${ }^{66}$ Ahmad Fauzi Abdul Hamid, "Islam and Violence in Malaysia," Singapore: S. Rajaratnam School of International Studies, No. 123, 9 March 2007, p. 3.

${ }^{67}$ Ucko, "The Malayan Emergency," p. 14.
} 